\title{
NUMERICAL MODELING OF OPEN PIT (OP) TO UNDERGROUND (UG) TRANSITION IN COAL MINING
}

\author{
PHu Minh VuOng NGUYen, ZBigniew NiEdBALSKI \\ AGH University of Science and Technology. \\ E-mail: nguyen@agh.edu.pl; niedzbig@agh.edu.pl
}

\begin{abstract}
The primary objective of the present paper is an attempt at evaluating the influence of sub-level caving operations on the slope stability of a still-functioning open pit coal mine in Vietnam. Initially, various methods of predicting the impact of underground mining on surface stability are discussed. Those theoretical considerations were later utilized in the process of constructing a Flac-2D-software-based numerical model for calculating the influence of underground operation on the deformation and possible loss of stability of an open pit slope. The numerical analysis proved that the values of open pit slope displacements were affected mainly by underground exploitation depth, direction of operation (i.e., from one slope to the other) and the distance from the slope plane. Real geomechanical strata parameters from the Vietnamese coal basin of Cam Pha were used in the modeling process. The paper is, therefore, a critical review of the hitherto proposed methods of predicting the impact of underground operation (UG) on open pit mining (OP), illustrated with selected examples of case studies on OP-UG interaction, followed by an original experiment based on numerical modeling method. This is first such study for the genuine conditions of the coal mining in Vietnam. The obtained results, however, should not be generalized due to a highly specific character of the analyzed phenomenon of mining-induced surface deformation. The practical implications of the study may occur extremely useful in the case of an UG-OP transition. Such a transition is often necessary for both technical and economical reasons, as in some coal basins open pit operations at greater depths occur unfeasible, which calls for a proper selection of parameters for a planned underground operation.
\end{abstract}

Key words: coal mining, numerical modeling, transition from OP to UG, surface deformation

\section{INTRODUCTION}

A dynamic development of civilization results in a highly increased demand for natural resources. It applies to almost all types of resources, such as: en- ergy resources, metals and rock minerals. In the case of open pit mines or underground mines, their operation is nowadays being run at constantly increasing depths, whereas in the case of open pit mines, further increase of exploitation depth proves impossible due to economic and technological limitations, as well

Table 1. Overview of major historical and future OP-UG transitions for ore body mining (modified after Visser [27])

\begin{tabular}{|c|c|c|c|c|}
\hline \multirow{2}{*}{ Country } & Mine name & Company & $\begin{array}{c}\text { Transition } \\
\text { year }\end{array}$ & Main product \\
\hline \multirow{2}{*}{ Australia } & Argyle & Rio Tinto & 2010 & Diamonds \\
\cline { 2 - 5 } & Fosterville & Perseverance & 2006 & Gold \\
\hline \multirow{2}{*}{ Canada } & Kidd Creek & Falconbridge & 1973 & Copper, Nickel \\
\cline { 2 - 5 } & Stobie & Inco & 1948 & Copper, Nickel \\
\hline \multirow{2}{*}{ Chile } & Chuquicamata & Codelco & 2019 & Copper \\
\cline { 2 - 5 } & Mansa Mina & Codelco & 2020 & Copper \\
\hline Indonesia & Grasberg & Rio Tinto & 2017 & Copper, Gold \\
\hline \multirow{2}{*}{ Russia } & Mir & Alrosa & 2001 & Diamonds \\
\cline { 2 - 5 } & Udachny & Alrosa & 2010 & Diamonds \\
\hline \multirow{2}{*}{ South } & Finsch & DeBeers & 1990 & Diamonds \\
\cline { 2 - 5 } Africa & Palabora & Rio Tinto & 2001 & Copper \\
\cline { 2 - 5 } & Venetia & DeBeers & 2021 & Diamonds \\
\hline Sweden & Kiruna & LKAB & 1958 & Iron \\
\hline USA & Bingham Canyon & Rio Tinto & 2018 & Copper \\
\hline
\end{tabular}


as safety measures. Moreover, many mines constitute a significant part of the regional or country economy. Liquidating those mines would have negative national economic implications, such as loss of tax income and increased dependence on foreign resources (Visser [27]). This situation also takes place in some open pit coal mines in Vietnam, which are planning to change the exploitation method. In the mining world, for a number of reasons, the size of mining operations considering an OP-UG transition is strongly increasing (Table 1). In the decision-making process, various factors should be taken under consideration. One of them is an assessment of the impact of underground mining on the stability of pit slopes.

\section{SURFACE SUBSIDENCE PREDICTION}

Generally, after any mineral exploitation, the breach of the structure of the rock mass will occur with distinctive features, depending on the method of underground exploitation (Fig. 1 and Fig. 2). In the case of longwall methods for coal exploitation, there are three zones: caved zone, fractured zone and sagging zone, which will appear above coal seam after exploitation (Fig. 1). A number of empirical formulas were developed in order to determine the impact of these zones on the volume of surface subsidence: Znański [33], Lisowski [14], Ropski [22], Sałustowicz [23], Staroń [25], Peng and Chiang [19], Peng [19], Bai et al. [2], Mazurkiewicz et al. [15].

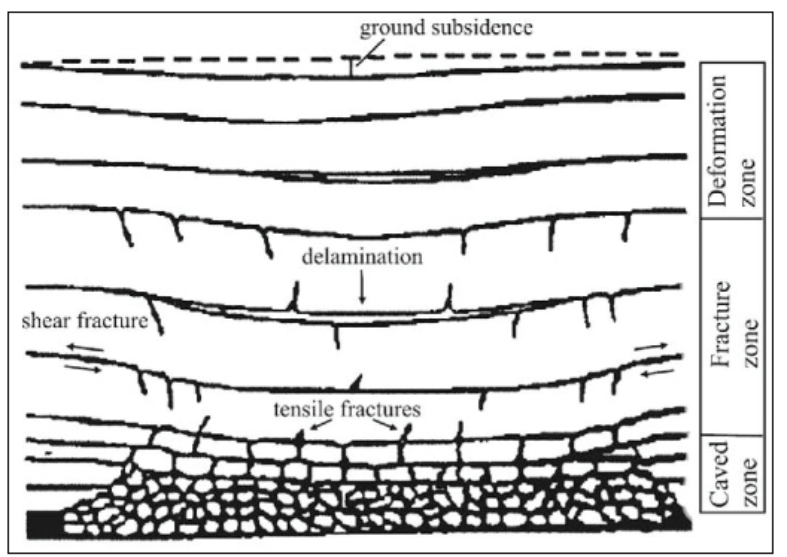

Fig. 1. Caved zone, fractured zone and sagging zone formed after exploitation of a longwall coal-mining panel (after Peng and Chiang [19])

Over the years, many theories were also developed in order to predict mining-induced surface deformation. Further details on the subject can be found, inter alia, in the following works: Gonot (1858), Dumont
(1871), Fayol (1885), Halbaum (1903), Schmitz (1923), Keinhorst (1925), Bals (1931). In the following years, Bals' method was supplemented and modified by various researchers, mostly by German authors. Bals' ideas were developed in the fullest form of geometrical integral theories by Polish researchers in the 1950's (Knothe [11]; Budryk [4]; Kochmański [13]).

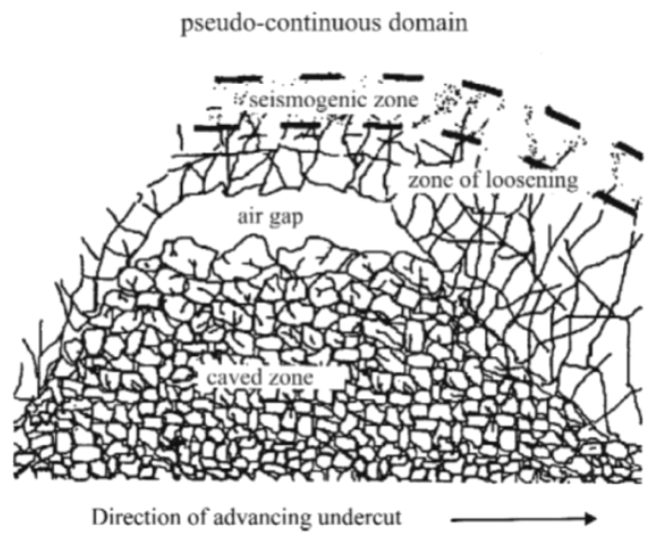

Fig. 2. Conceptual model of caving (after Duplancic and Brady [6])

Based on the theory of Knothe [11], [12], the concept of determining the range of influences, called "the radius of main influences" $r(z)$, was published by Piwowarski et al. [21]. In late 1990's, Xueyi Yu presented a method based on the theory of Knothe to predict displacements and deformations in mountainous areas for coal mining conditions in China (Yu [32]).

In mining practice, most commonly used methods to predict the surface deformation are geometricalintegral methods, based on the influences functions describing the shape of the trough. The methods of surface deformation prediction are effective for horizontal or almost horizontal areas, as well as for one single coal seam operation. However, surface deformation prediction is much more difficult for the operation of multi coal seams and complex topography.

In addition, empirical methods fail to characterize the interaction between layers of rocks, hence they do not allow taking into account a number of factors (i.e., factors related to geological structure, rock mass properties, the presence of discontinuities and underground water). Each mine is characterized by a unique combination of geological and mining conditions. Ignoring geotechnical factors may lead to conditions of high risk and thus result in loss of material, equipment and/or personnel. Hence, the prediction of the impact of underground mining on slope surface by using analytical or empirical methods proves unsatisfactory for a comprehensive analysis of subsidence/ deformation prediction. 
Table 2. Numerical studies of caving-induced surface subsidence (Vyazmensky [28])

\begin{tabular}{|l|c|c|}
\hline \multicolumn{1}{|c|}{ Authors } & Code & Type of analysis \\
\hline Singh et al. (1993) & FLAC 2D & Rajpura Daribaand Kiruna \\
\hline Karzulovic et al. (1999) & FLAC 2D & El Teniente \\
\hline Van As (2003) & FLAC 3D & Northparkes \\
\hline Cavieres et al. (2003) & 3DEC & El Teniente \\
\hline Flores and Karzulovic (2004) & FLAC 2D and FLAC 3D & Conceptual \\
\hline Gilbride et al. (2005) & PFC 3D & Questa \\
\hline Brummer et al. (2006) & 3DEC & Palabora \\
\hline Elmo et al. (2007) & FLAC 3D & San Manuel \\
\hline Villegas \& Nordlund (2008) & Phase2, PFC 2D & Kiruna \\
\hline
\end{tabular}

In recent years, with the development of computer science, numerical methods become more and more popular in solving problems of geo-engineering. They prove particularly useful when their results are used for comparison with the results of observations under natural conditions. Issues related to displacement and surface deformation predictions are also solved by means of applying numerical methods.

For ore-body mining using underground method of "caving", the most important works in the field of surface deformation prediction are presented in Table 2.

In Poland, the implementation of numerical methods for surface deformation prediction in coal mining using the "longwall" underground method was presented by Kwaśniewski and Wang [10], Tajduś [26], Florkowska [7], Wesołowski et al. [29] and Wesołowski [30]. In his work, Tajduś performed an analysis for dozens of models: linear-elastic, nonlinear-elastic, elastic-plastic, and compared the results with the results obtained from Knothe's theory. He argued that with suitable properties for "transversally isotropic" numerical model, surface displacements obtained are close to the results measured under natural conditions. The study was carried out with the use of finite element method (FEM). Wesołowski, by means of the appropriate selection of properties for a transversally isotropic model, also obtained results consistent with Knothe's theory. The research was performed with the application of finite difference method (FDM) using FLAC 3D code.

\section{CASE STUDIES ON UG-OP INTERACTION}

Mining activity is one of the most important factors affecting the change of natural phenomena in the rock mass. Underground operation causes subsidence, slope movements, discontinuous deformations and change of hydrogeological conditions. In the case of underground operation located below the open pit mine, slope strain can be expected as a result of subsidence induced by underground exploitation. Changes in physical and mechanical properties of rock mass, groundwater levels and the state of stress inside the slope can lead to slope deformation.

\section{Enormous disaster at the mine Palabora, South Africa}

Palabora mine is one of the steepest and deepest large open pits in the world, with a radius of about $1.5 \mathrm{~km}$, and a depth of about $800 \mathrm{~m}$. The transition from open pit to block caving embraced extracting a $400 \mathrm{~m}$ column below the pit floor (Fig. 3). The geology of the mine (a volcanic plug) is extremely complex. Besides various rock types (up to ten types at the mine) with different properties, there are four main faults crossing the pit and three dominant joint sets ubiquitous in the mine. Ground water is also present (Brummer et al. [3]).

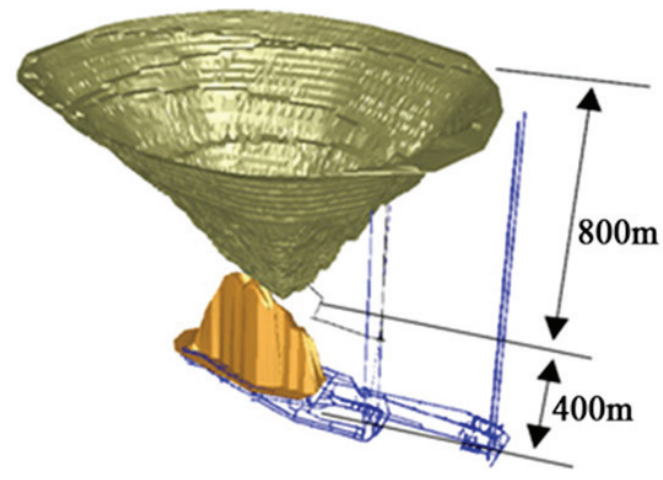

Fig. 3. Three-dimensional model of pit and cave at Palabora mine (Brummer et al. [3])

Seismic monitoring data indicates that the crown pillar failed in April 2004 with the cave breaking through to the open pit. Subsequent to this was a ma- 
jor open pit wall failure that occurred in September 2004. The failure dimensions were some $800 \mathrm{~m}$ in height by $300 \mathrm{~m}$ along the wall, with the crest of approx. $50 \mathrm{~m}$ back from the pit rim. Nearly 130 million tons of waste filled the North-West corner and the floor of the open pit (Fig. 4). A physical model was constructed in 2005 and the impact of waste material on the ore reserves was quantified with the use of Rebop (particle flow simulation software). Results indicated that there would be approximately 30 per cent of ore reserve loss (Ngidi and Boshoff [18]).

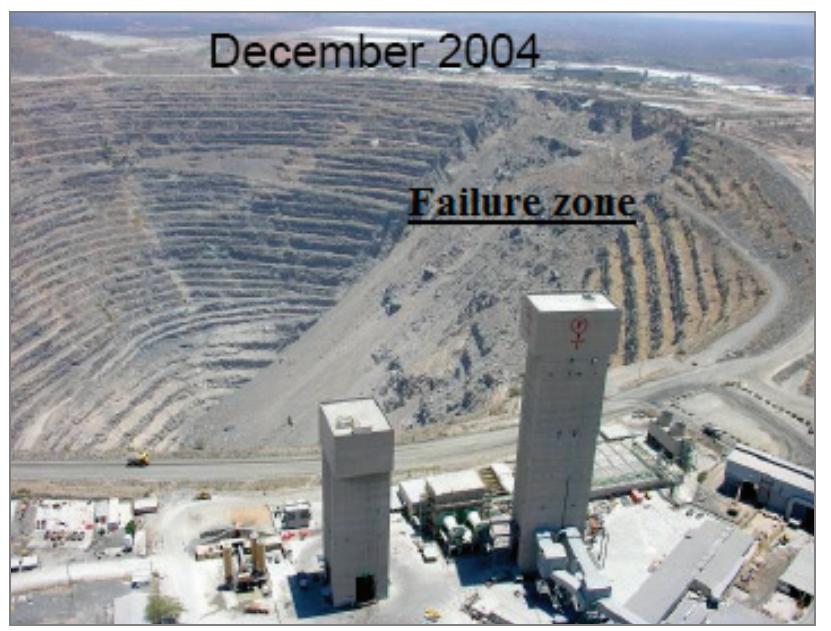

Fig. 4. Failure at Palabora mine (modified after Ngidi and Boshoff [18])

In order to determine the phenomena occurring inside the rock mass, which led to the catastrophe, and predict further damage, many numerical analyses have been carried out, including: Brummer et al. [3]; Moss et al. [16]; Vyazmensky [28]; Severini et al. [24]; Woo et al. [31]; Ngidi et al. [18]; Ahmed et al. [1].

\section{Sublevel caving and open pit interaction at the Ernest Henry mine, Australia}

At the Ernest Henry mine, the open pit operated to 2011 and had its final dimensions of $1.5 \mathrm{~km}$ by $1.3 \mathrm{~km}$ at a $530 \mathrm{~m}$ depth. Sublevel caving production began after completion of the open pit with the planned cave footprint of a $220 \mathrm{~m}$ column (Fig. 5).

Pit failure started to occur after the pillar had been removed and the initial sublevel had been completed in late 2012. A large collapse occurred in December 2014 (Fig. 6). From laser scanning, the estimated volume was $935,000 \mathrm{~m}^{3}$ (about $2.5 \mathrm{Mt}$ of rock). The failure dimensions measured about $200 \mathrm{~m}$ wide, $150 \mathrm{~m}$ high and $30 \mathrm{~m}$ thick. More details about this case can be found in the study of Campbell et al. [5].

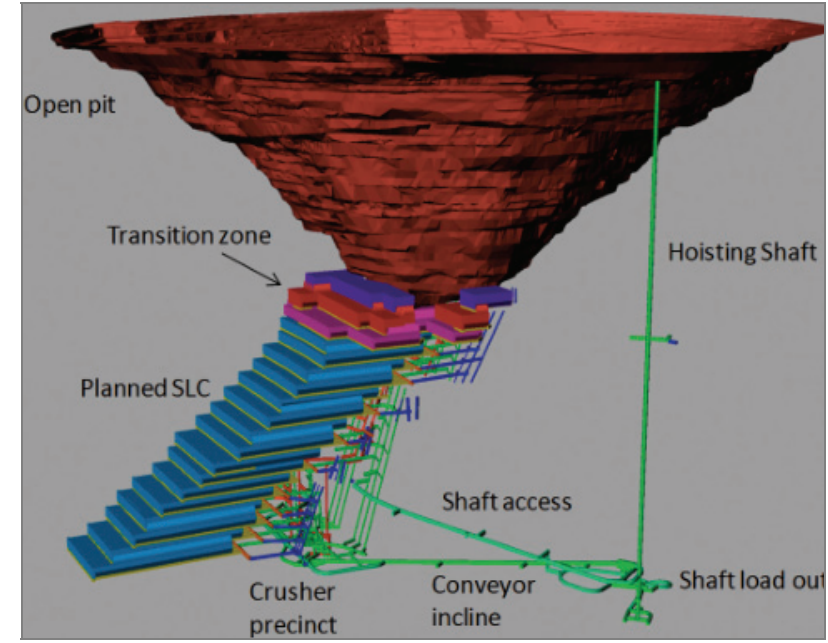

Fig. 5. Three dimensional view of the sublevel cave and final pit at the Ernest Henry mine (Campbell et al. [5])

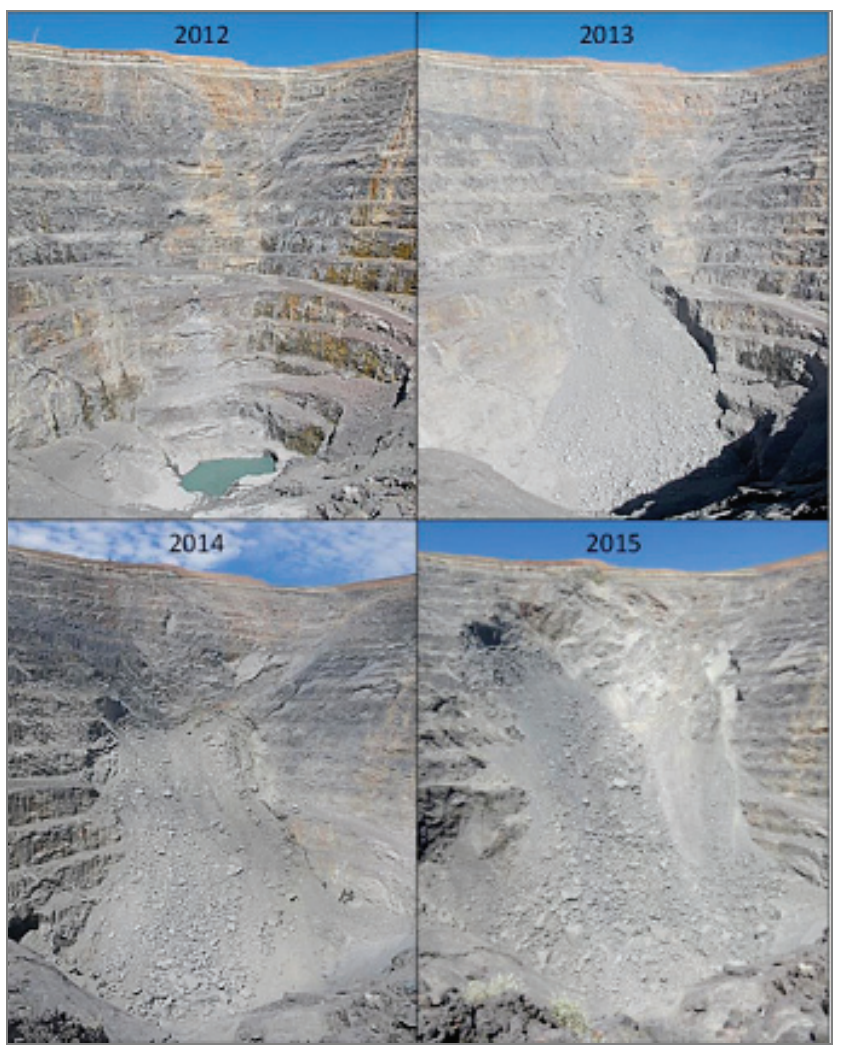

Fig. 6. Progression of caving-induced pit wall failure (Campbell et al. [5])

The examples above seem to provide a clear warning regarding the possible impact of underground mining on open pit mines. Therefore, it is necessary to carry out more research and analysis on slope stability of open pit affected by underground mining. Due to the different geological conditions and the technology application, any such case should be analyzed individually. 
In Vietnam, a decision of transition from OP to UG has been made for coal mining after a number of investigations. The operating mode will be changed from OP to UG. However, before finishing the OP operation proper, both OP and UG mining will have to be run simultaneously. Due to this fact, in order to understand the interaction between UG and OP, a conceptual numerical analysis was carried out for specific geological and mining conditions of coal mining in Vietnam.

\section{NUMERICAL MODELING}

\subsection{IMPLEMENTATION \\ OF THE MOHR-COULOMB MODEL IN SOFTWARE PROGRAM-CODE FLAC 2D}

The failure envelope for this model corresponds to a Mohr-Coulomb criterion (shear yield function) with tension cutoff (tensile yield function). The shear flow rule is non-associated, and the tensile flow rule is associated.

The Mohr-Coulomb model allows for plasticity of the rock mass, which is the non-linearity of its stressstrain characteristics. The plastic flow formulation in FLAC rests on basic assumptions from plasticity theory that the total strain increment may be decomposed into elastic and plastic parts, with only the elastic part contributing to the stress increment by means of an elastic law. In addition, both plastic and elastic strain increments are taken to be coaxial with the current principal axes of the stresses. (This is only valid if elastic strains are small compared to plastic strains during plastic flow). The flow rule specifies the direction of the plastic strain increment vector as that normal to the potential surface; it is called associated if the potential and yield functions coincide, and nonassociated otherwise.

In the FLAC implementation of the Mohr-Coulomb model, principal stresses $\sigma_{1}, \sigma_{2}, \sigma_{3}$ are used with the main assumption

$$
\sigma_{1} \leq \sigma_{2} \leq \sigma_{3} .
$$

The corresponding principal strain increments $\Delta e_{1}$, $\Delta e_{2}, \Delta e_{3}$ are decomposed

$$
\Delta e_{i}=\Delta e_{i}^{e}+\Delta e_{i}^{p} ; \quad i=1,3
$$

where $\Delta e_{i}^{e}$ is the elastic strain and $\Delta e_{i}^{p}$ is the plastic strain (the plastic components are nonzero only during plastic flow).
The incremental expression of Hooke's law in terms of principal stress and strain has the form

$$
\begin{aligned}
& \Delta \sigma_{1}=\alpha_{1} \Delta e_{1}^{e}+\alpha_{2}\left(\Delta e_{2}^{e}+\Delta e_{3}^{e}\right), \\
& \Delta \sigma_{2}=\alpha_{1} \Delta e_{2}^{e}+\alpha_{2}\left(\Delta e_{1}^{e}+\Delta e_{3}^{e}\right), \\
& \Delta \sigma_{3}=\alpha_{1} \Delta e_{1}^{e}+\alpha_{2}\left(\Delta e_{1}^{e}+\Delta e_{2}^{e}\right),
\end{aligned}
$$

where $\alpha_{1}=K+3 G / 3$ and $\alpha_{2}=K-2 G / 3 ; K-$ bulk modulus; $G$ - shear modulus.

The failure criterion in the plane $\left(\sigma_{1}, \sigma_{3}\right)$ is presented in Fig. 7.

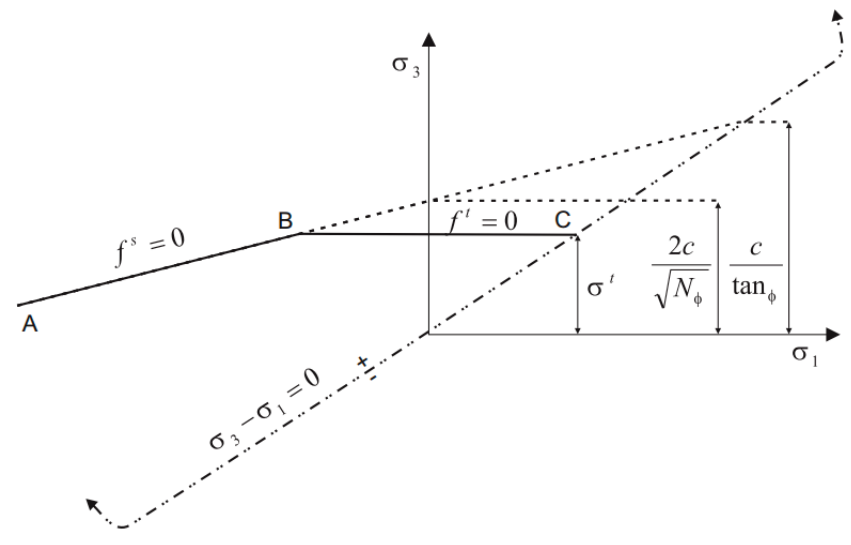

Fig. 7. The Mohr-Coulomb failure criterion in FLAC (Itasca [9])

The failure envelope is defined from point $\mathrm{A}$ to point B by the Mohr-Coulomb (shear) yield function

$$
\begin{gathered}
f^{s}=\sigma_{1}-\sigma_{3} N_{\theta}+2 c \sqrt{N_{\theta}}, \\
N_{\theta}=\frac{1+\sin \theta}{1-\sin \theta},
\end{gathered}
$$

and from $\mathrm{B}$ to $\mathrm{C}$ by tension yield function

$$
f^{t}=\sigma^{t}-\sigma_{3}
$$

where $\theta$ is the friction angle, $c$ is the cohesion, $\sigma^{t}$ is the tensile strength.

It should be noted that the intermediate principal stress has no effect in the shear yield formulation. For a material with friction, $\theta \neq 0$, the tensile strength of the material cannot exceed the maximum value given by

$$
\sigma_{\max }^{t}=\frac{c}{\tan \theta}
$$

The shear potential function, $g^{s}$, corresponds to a non-associated flow rule and has the form 


$$
\begin{gathered}
g^{s}=\sigma_{1}-\sigma_{3} N_{\psi}, \\
N_{\Psi}=\frac{1+\sin \Psi}{1-\sin \Psi},
\end{gathered}
$$

where $\psi$ is the dilation angle.

The associated flow rule for tensile failure is derived from the potential function in the form

$$
g^{t}=-\sigma_{3} .
$$

The flow rules for this model are given a unique definition in the vicinity of the edge of the composite yield function in three dimensional stress space for the case of shear-tension edge. The function is presented by the diagonal between the presentation of shear yield function and tension yield function in the plane $\left(\sigma_{1}, \sigma_{3}\right)$

$$
\begin{gathered}
h=\sigma_{3}-\sigma^{t}+\alpha^{P}\left(\sigma_{1}-\sigma^{P}\right), \\
\alpha^{P}=\sqrt{1+N_{\theta}^{2}}+N_{\theta}, \\
\sigma^{P}=\sigma^{t} N_{\theta}-2 c \sqrt{N_{\theta}} .
\end{gathered}
$$

The flow rule has the form

$$
\Delta e_{i}^{p}=\lambda^{s} \frac{\partial g^{s}}{\partial \sigma_{i}} ; \quad i=1,3
$$

where $\lambda^{s}$ is an unknown parameter. Using equation (7) for $g^{s}$, these equations become, after partial differentiation,

$$
\begin{gathered}
\Delta e_{1}^{p}=\lambda^{s}, \\
\Delta e_{2}^{p}=0, \\
\Delta e_{3}^{p}=-\lambda^{s} N_{\psi} .
\end{gathered}
$$

The elastic strain increments may be expressed from equation (2) as total increment minus plastic increment. In further using equation (11), the elastic laws in equation (3) become

$$
\begin{gathered}
\Delta \sigma_{1}=\alpha_{1} \Delta e_{1}+\alpha_{2}\left(\Delta e_{2}+\Delta e_{3}\right)-\lambda^{s}\left(\alpha_{1}-\alpha_{2} N_{\psi}\right), \\
\Delta \sigma_{2}=\alpha_{1} \Delta e_{2}+\alpha_{2}\left(\Delta e_{1}+\Delta e_{3}\right)-\lambda^{s} \alpha_{2}\left(1-N_{\psi}\right), \\
\Delta \sigma_{3}=\alpha_{1} \Delta e_{3}+\alpha_{2}\left(\Delta e_{1}+\Delta e_{2}\right)-\lambda^{s}\left(-\alpha_{1} N_{\psi}+\alpha_{2}\right) .
\end{gathered}
$$

Let the new and old stress states be referred to by the superscripts $N$ and $O$, respectively. Then, by definition

$$
\sigma_{i}^{N}=\sigma_{i}^{O}+\Delta \sigma ; \quad i=1,3 .
$$

Substituting equation (12) we may write

$$
\begin{gathered}
\sigma_{1}^{N}=\sigma_{3}^{I}-\lambda^{s}\left(\alpha_{1}-\alpha_{2} N_{\psi}\right), \\
\sigma_{2}^{N}=\sigma_{2}^{I}-\lambda^{s} \alpha_{2}\left(1-N_{\psi}\right), \\
\sigma_{3}^{N}=\sigma_{3}^{I}-\lambda^{s}\left(-\alpha_{1} N_{\psi}+\alpha_{2}\right),
\end{gathered}
$$

where the superscript $I$ is used to represent the elastic guess, obtained by adding the old stress elastic increments computed using the total strain increments

$$
\begin{aligned}
& \sigma_{1}^{I}=\sigma_{1}^{O}+\alpha_{1} \Delta e_{1}+\alpha_{2}\left(\Delta e_{2}+\Delta e_{3}\right), \\
& \sigma_{2}^{I}=\sigma_{2}^{O}+\alpha_{1} \Delta e_{2}+\alpha_{2}\left(\Delta e_{1}+\Delta e_{3}\right), \\
& \sigma_{3}^{I}=\sigma_{3}^{O}+\alpha_{1} \Delta e_{3}+\alpha_{2}\left(\Delta e_{1}+\Delta e_{2}\right) .
\end{aligned}
$$

The parameter $\lambda^{s}$ may now be defined by requiring that the new stress point be located on the shear yield surface

$$
\lambda^{s}=\frac{f^{s}\left(\sigma_{1}^{I}, \sigma_{3}^{I}\right)}{\left(\alpha_{1}-\alpha_{2} N_{\psi}\right)-\left(-\alpha_{1} N_{\psi}+\alpha_{2}\right) N_{\psi}} .
$$

In the case of tensile failure, the flow rule has the form

$$
\Delta e_{i}^{p}=\lambda^{t} \frac{\partial g^{t}}{\partial \sigma_{i}} ; \quad i=1,3
$$

where $\lambda^{t}$ is unknown parameter. Using equation (8) for $g^{t}$, these equations become, after partial differentiation

$$
\begin{gathered}
\Delta e_{1}^{p}=0, \\
\Delta e_{2}^{p}=0, \\
\Delta e_{3}^{p}=-\lambda^{t} .
\end{gathered}
$$

Repeating a reasoning similar to that described above, we obtain

$$
\begin{aligned}
& \sigma_{1}^{N}=\sigma_{1}^{I}+\lambda^{t} \alpha_{2}, \\
& \sigma_{2}^{N}=\sigma_{2}^{I}+\lambda^{t} \alpha_{3}, \\
& \sigma_{3}^{N}=\sigma_{3}^{I}+\lambda^{t} \alpha_{1},
\end{aligned}
$$

and

$$
\lambda^{t}=\frac{f^{t}\left(\sigma_{3}^{I}\right)}{\alpha_{1}} .
$$

These formulas allow the components of the stress state to be determined in each step of the calculation. Knowing the stress we are able to calculate the com- 
ponents of the state of displacement in each node of the grid and determine the state of material effort, based on accepted values of strength parameters.

\subsection{MODEL DESCRIPTION}

Prediction of interaction between UG and OP was carried out with the application of Flac 2D software based on Finite Difference Method (Itasca). All parameters of rock mass used for the modeling are based on laboratory tests for geological and mining conditions of Quang Ninh coal basin in Vietnam (Table 3).

In order to determine the geometry of the model, the heights of the caved zone $h_{z w}$ and the fractured zone $h_{s}$ were calculated. Their mechanical properties are different depending on the rock mass intact and strongly affect the surface deformation shape. These parameters are defined by the formulas below (Kendorski, Roosendaal and Bai [2])

$$
h_{z w}=\frac{100 g}{c_{1} g+c_{2}}, \quad h_{s}=\frac{100 g}{c_{2} g+c_{4}}
$$

where

$h_{z w}$ - height of caved zone, m;

$h_{s}$ - height of fractured zone, m;

$g$ - coal bed thickness, m;

$c_{1}, c_{2}, c_{3}, c_{4}-$ constant coefficients dependent on compressive strength (Table 4).

Rock mass in the basin Cam Pha is classified as strong and hard, so the height of the caved zone is approximately $13 \mathrm{~m}$, while the height of the fractured zone is approximately $53 \mathrm{~m}$, assuming the coal bed thickness of $3.0 \mathrm{~m}$.

Since there is no access to the caved zone and the fractured zone, these zones were assumed as strongly cracked rock and cracked rock. Therefore, deformation and strength parameters were selected according to the investigations of Nawrot [17], which assumed that mechanical parameters of caved zone were 20-40 times lower and mechanical parameters of the fractured zone were 2-3 times lower than the parameters of intact rock located in the roof zone. The parameters of the caved zone and the fractured zone in longwall operation are presented in Table 5 after calibration process by using "back analysis" method and Knothe's theory. These parameters are dependent on the depth of longwall mining panel.

Table 3. Mechanical parameters of the rock mass used in numerical modeling

\begin{tabular}{|c|c|c|c|c|c|c|}
\hline Material & $\begin{array}{c}\text { Young } \\
\text { modulus } \\
E[\mathrm{GPa}]\end{array}$ & $\begin{array}{c}\text { Cohesion } \\
c[\mathrm{MPa}]\end{array}$ & $\begin{array}{c}\text { Tensile } \\
\text { strength } \\
\sigma^{t}[\mathrm{MPa}]\end{array}$ & $\begin{array}{c}\text { Friction } \\
\text { angle } \\
\theta\left[^{\circ}\right]\end{array}$ & $\begin{array}{c}\text { Poisson } \\
\text { ratio } \\
v[-]\end{array}$ & $\begin{array}{c}\text { Bulk } \\
\text { density } \\
\rho\left[\mathrm{kg} / \mathrm{m}^{3}\right]\end{array}$ \\
\hline Roof & 1.2 & 1 & 0.5 & 28 & 0.25 & 2,600 \\
\hline Coal & 1.4 & 1.2 & 0.6 & 30 & 0.25 & 1,500 \\
\hline Floor & 1.8 & 1.5 & 0.75 & 32 & 0.25 & 2,600 \\
\hline
\end{tabular}

Table 4. Coefficients for average height of caved zone and fractured zone (Kendorski, Roosendaal and Bai [2])

\begin{tabular}{|c|c|c|c|c|c|}
\hline \multirow{2}{*}{ Strata lithology } & Compressive & \multicolumn{4}{|c|}{ Coefficients } \\
\cline { 3 - 6 } & strength $[\mathrm{MPa}]$ & $c_{1}$ & $c_{2}$ & $c_{3}$ & $c_{4}$ \\
\hline Strong and hard & $>40$ & 2.1 & 16 & 1.2 & 2 \\
\hline Medium strong & $20 \div 40$ & 4.7 & 19 & 1.6 & 3.6 \\
\hline Soft and weak & $<20$ & 6.2 & 32 & 3.1 & 5 \\
\hline
\end{tabular}

Table 5. Mechanical parameters of caved zone and fractured zone

\begin{tabular}{|c|c|c|c|c|c|c|}
\hline Material & $\begin{array}{c}\text { Young's } \\
\text { modulus } \\
E[\mathrm{GPa}]\end{array}$ & $\begin{array}{c}\text { Cohesion } \\
c[\mathrm{MPa}]\end{array}$ & $\begin{array}{c}\text { Tensile } \\
\text { strength } \\
\sigma^{t}[\mathrm{MPa}]\end{array}$ & $\begin{array}{c}\text { Friction } \\
\text { angle } \\
\theta\left[{ }^{\circ}\right]\end{array}$ & $\begin{array}{c}\text { Poisson's } \\
\text { ratio } \\
v[-]\end{array}$ & $\begin{array}{c}\text { Bulk } \\
\text { density } \\
\rho\left[\mathrm{kg} / \mathrm{m}^{3}\right]\end{array}$ \\
\hline \multicolumn{7}{|c|}{ Coal seam is located at $400 \mathrm{~m}$ depth below pit crest (case study II) } \\
\hline Caved zone & 0.06 & 0 & 0 & 30 & 0.3 & 2,000 \\
\hline Fractured zone & 0.6 & 0.5 & 0.25 & 25 & 0.25 & 2,600 \\
\hline Coal seamed zone & 0.03 & 0 & 0 & 10 & 0.25 & 2,000 \\
\hline Fractured zone & 0.6 & 0.5 & 0.25 & 20 & 0.25 & 2,600 \\
\hline
\end{tabular}


Figure 8 shows the dimensions of the numerical model and the location of the caved zone and the fractured zone above the longwall panel. The numerical model consists of 12524 zones and fixed (restrained) bottom and two sides

It was assumed that the rock mass was stratified with the properties according to the elastic-plastic model of Mohr-Coulomb. The initial model was solved as an elastic model in order to obtain the initial stress conditions. Then, the vectors and speeds of displacements were zeroed. The next step was assigning the "null" model to the zone corresponding to the caved zone and the fractured zone, and re-assigning the Mohr-Coulomb model with equivalent parameters to those zones and calculating it again.
Calculations were performed for three variants (cases) (Fig. 8).

Case I: the coal seam is located at $150 \mathrm{~m}$ depth below the pit floor. Location of the longwall panel is changed every $100 \mathrm{~m}$ along the horizontal axis. The geometry of the numerical model assumed the following longwall dimensions: $300 \mathrm{~m}$ in length and $3 \mathrm{~m}$ in height (Fig. 8).

Case II: the coal seam is located at $400 \mathrm{~m}$ depth below the slope crest. Longwall operation proceeds from the left side to the upper edge with the advancement rate of $100 \mathrm{~m}$ (Fig. 9).

Case III: coal seam is located at $150 \mathrm{~m}$ depth below pit floor. Long wall operation proceeds from the right side to the lower edge with the advancement rate of $100 \mathrm{~m}$ (Fig. 10).

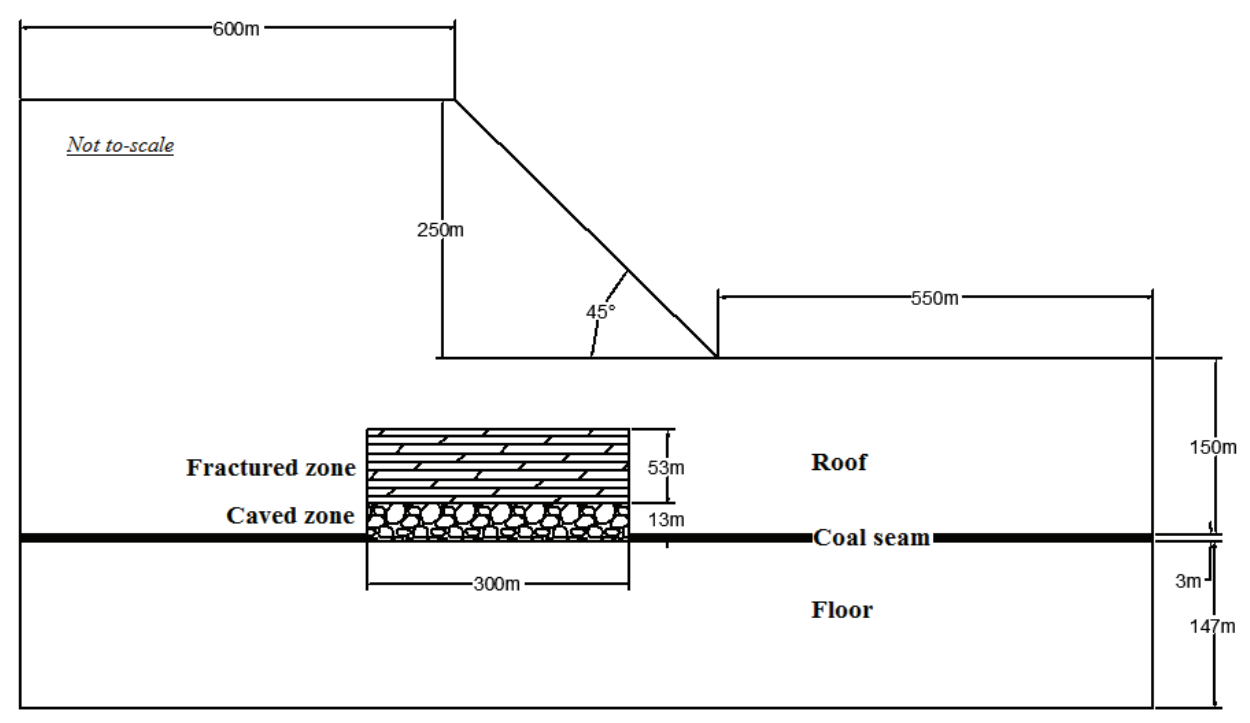

Fig. 8. Two-dimensional numerical model and location of rock layers

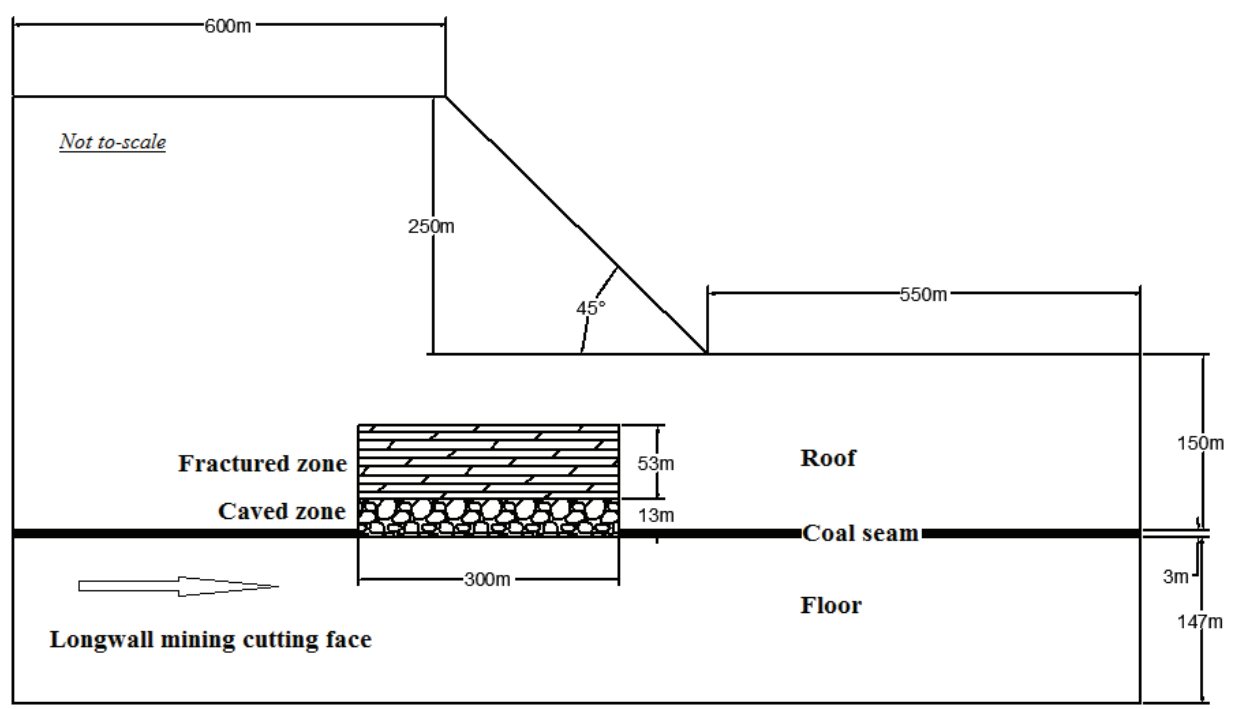

Fig. 9. Two-dimensional numerical model dal case study II 


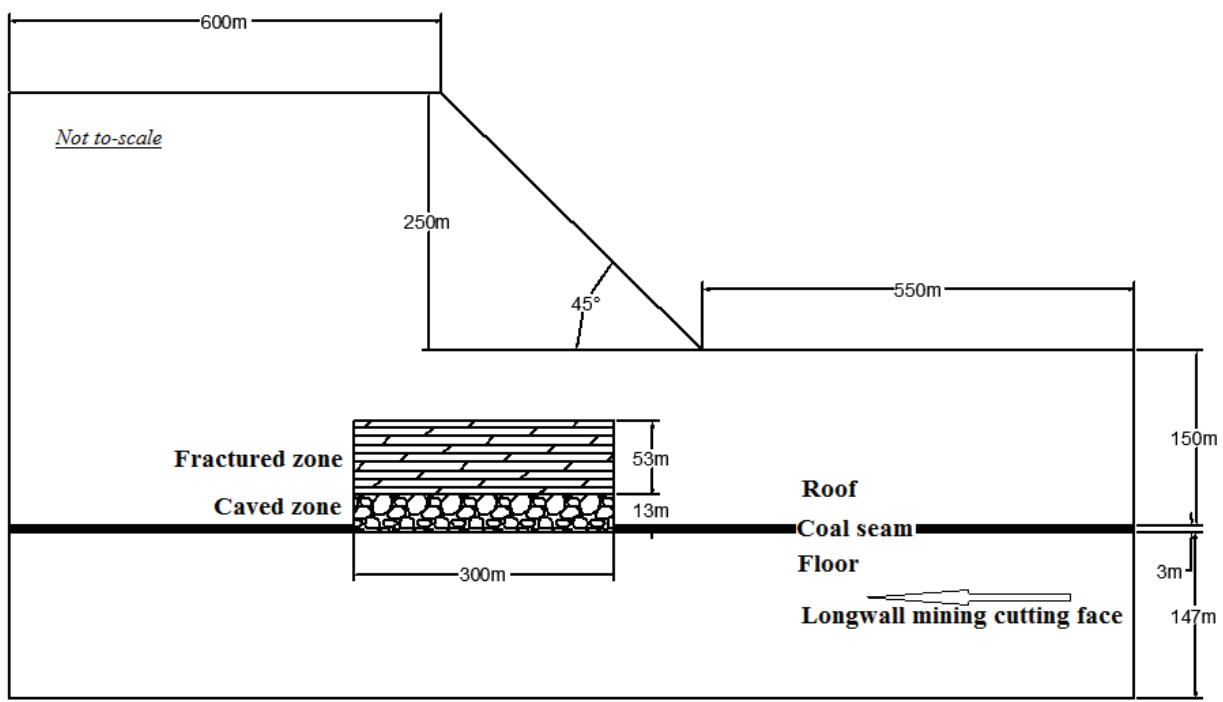

Fig. 10. Two-dimensional numerical model dal case study III.

Note: Speed of exploitation is omitted, only the size of coal extraction has been taken into account.

Cutting face advanced every $100 \mathrm{~m}$ toward open pit slope

\section{ANALYSIS OF RESULT}

The displacements, plasticity and velocity vectors were analyzed in order to assess the impact of underground mining on open pit slope. Slope deformation generated by longwall operation may lead open pit slope to the loss of stability.

Case I: The longwall panel

is located perpendicularly to the model

For this model the position of the longwall panel changed at a constant depth along the horizontal axis in relation to the open pit slope. Figure 11 shows vertical displacement of the slope face depending on the position of the longwall panel, wherein the distance measured is the center of the longwall panel. Calculations show that the largest vertical displacements along the slope face can be expected when the center of the longwall panel was located in the range of distances from $150 \mathrm{~m}$ before the upper edge to $250 \mathrm{~m}$ behind the upper edge. The values of subsidence are in the range from 1.13 to $2.1 \mathrm{~m}$. The horizontal displacements also indicated that, for the above position of the longwall panels, they can be significant up to $1.1 \mathrm{~m}$ in the direction of pit slope (Fig. 12). Such movements may be an impulse for the loss of slope stability. This is confirmed by plasticity indicators, which show that slope failures may occur in particular areas (Fig. 13).

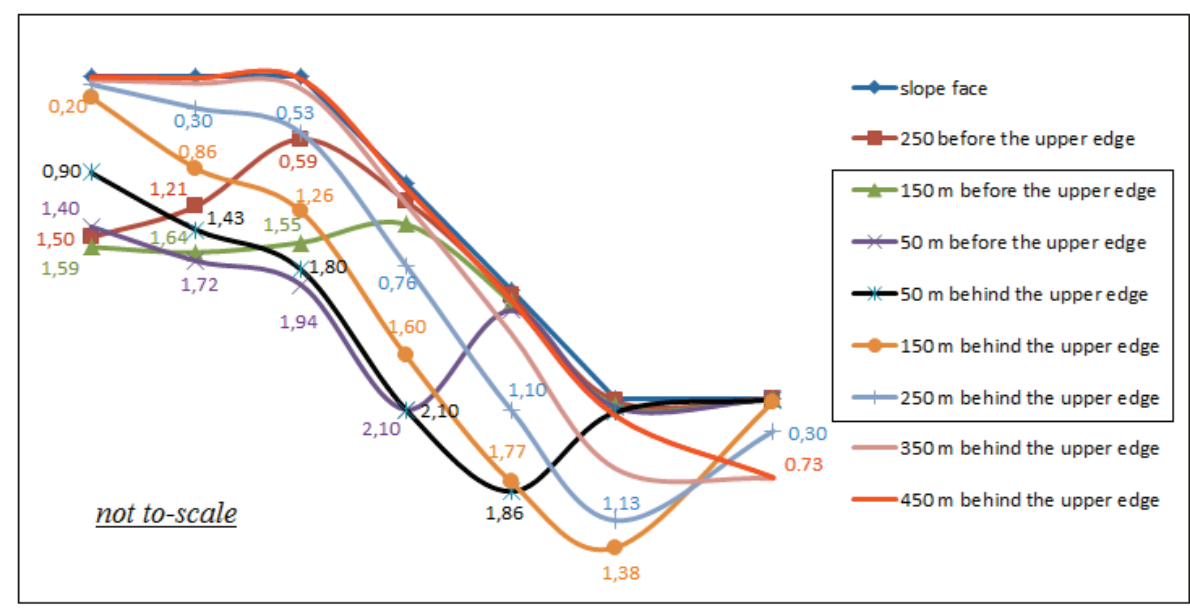

Fig. 11. Vertical displacements of slope face at different positions of longwall panel (measured point is the center of the longwall panel) 


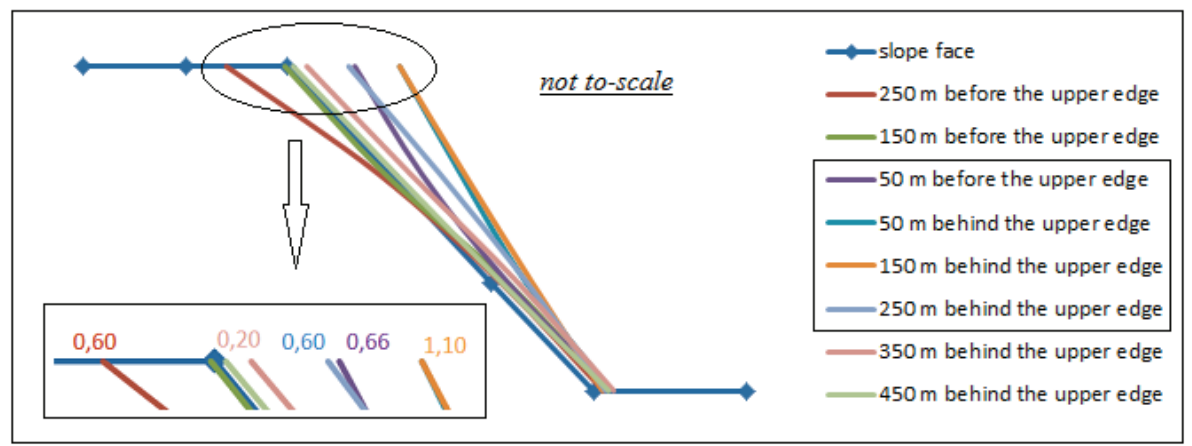

Fig. 12. Horizontal displacements of slope face at different positions of longwall panel (measured point is the center of the longwall panel)

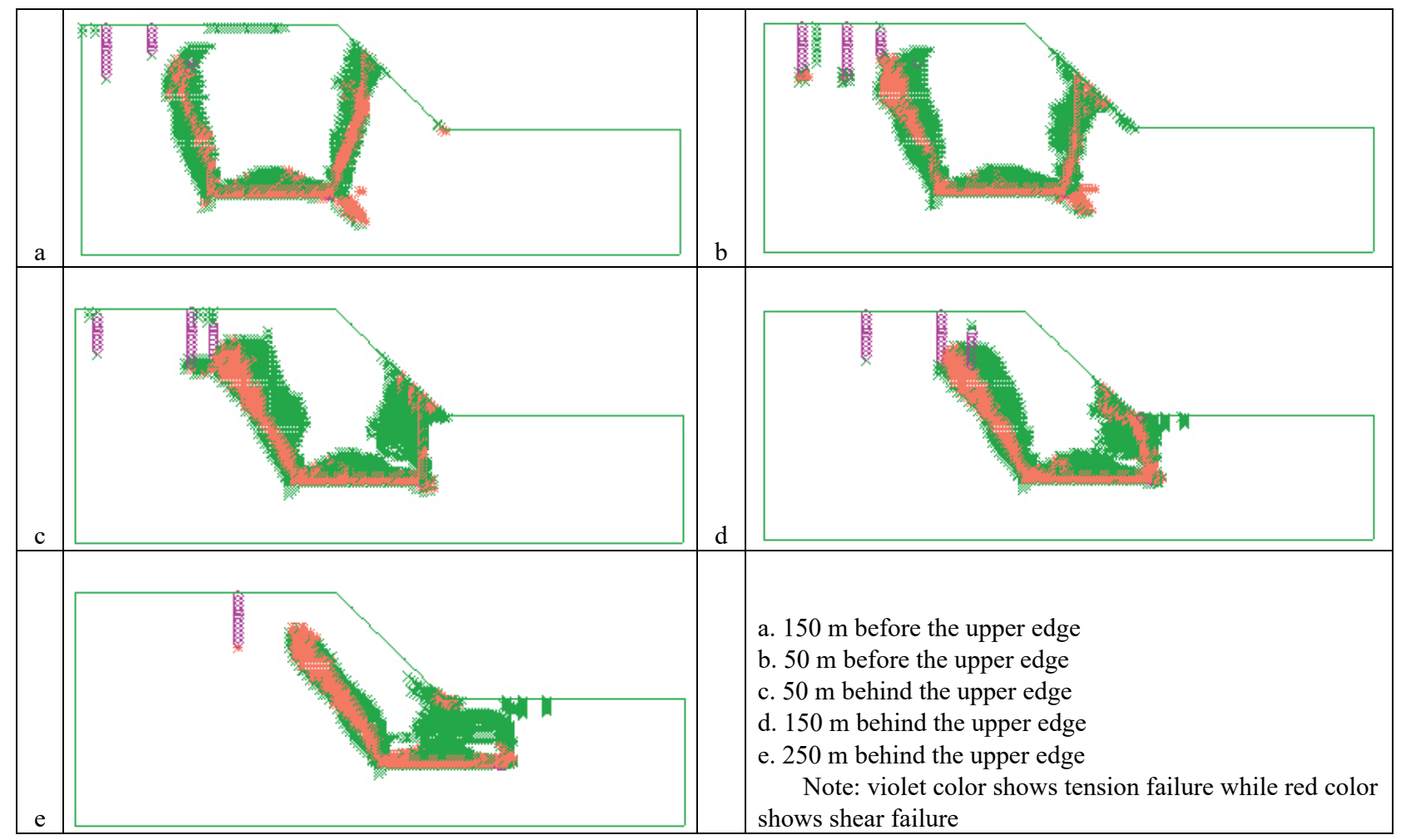

Fig. 13. Plasticity indicator of rock mass at different positions of longwall panel (measured point is the center of the longwall panel)

Case II: Longwall operation proceeds from the left side towards the upper edge of the open pit slope

The results calculated for this case indicate that the upper edge starts to move with a large extent when the long wall face reaches the distance of $100 \mathrm{~m}$ from the upper edge (Fig. 14). The maximum subsidence of the upper edge and slope occurs when the longwall face reaches $100 \mathrm{~m}$ behind the upper edge. Subsidence values are in the range of $1.4 \div 2.2 \mathrm{~m}$.

Horizontal displacements of Case II reach a value in the range of $0.5 \div 1.0 \mathrm{~m}$ (Fig. 15). In this case, the direction of movements leads to a reduction of the slope angle, which is advantageous from the point of view of slope stability. However, the displacement can lead to such changes in the properties of rock mass that can cause instability.

The increase of velocity vectors is almost 2 times for the situation when the longwall face is less than $200 \mathrm{~m}$ from the upper edge of the slope (Fig. 16c $\div$ e), which indicates the possibility of failure on the slope face. The direction of velocity vectors, as well as the direction of displacement, however, is advantageous from the point of view of slope stability. Nevertheless, it may weaken the rock mass and lead to the loss of slope stability in the future. 


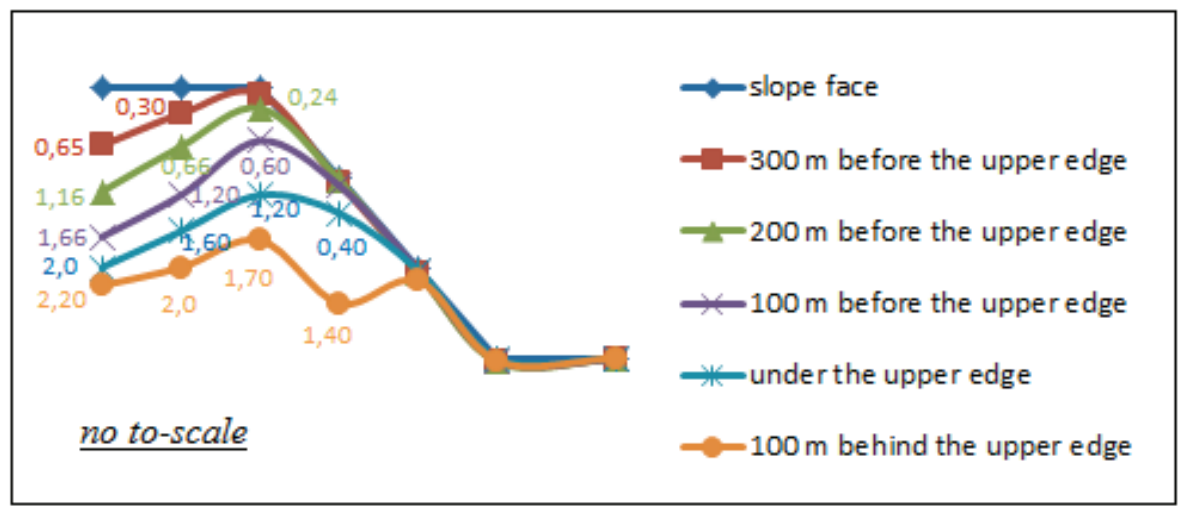

Fig. 14. Vertical displacement of slope face when the longwall operation proceeds from the left side towards the upper edge of slope (measured point is the face of the longwall panel)

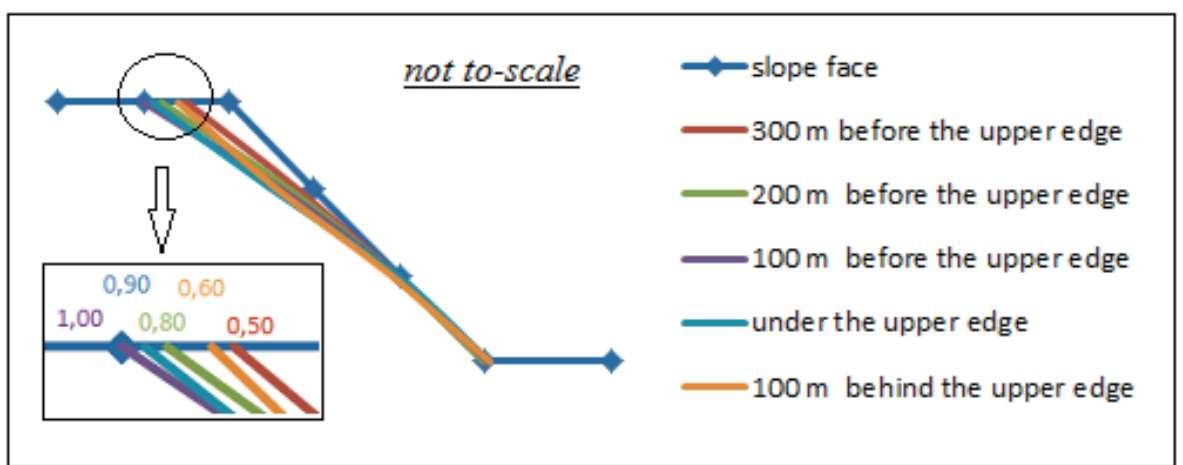

Fig. 15. Horizontal displacement of slope face when the longwall operation proceeds from the left side towards the upper edge of slope (measured point is the face of the longwall panel)

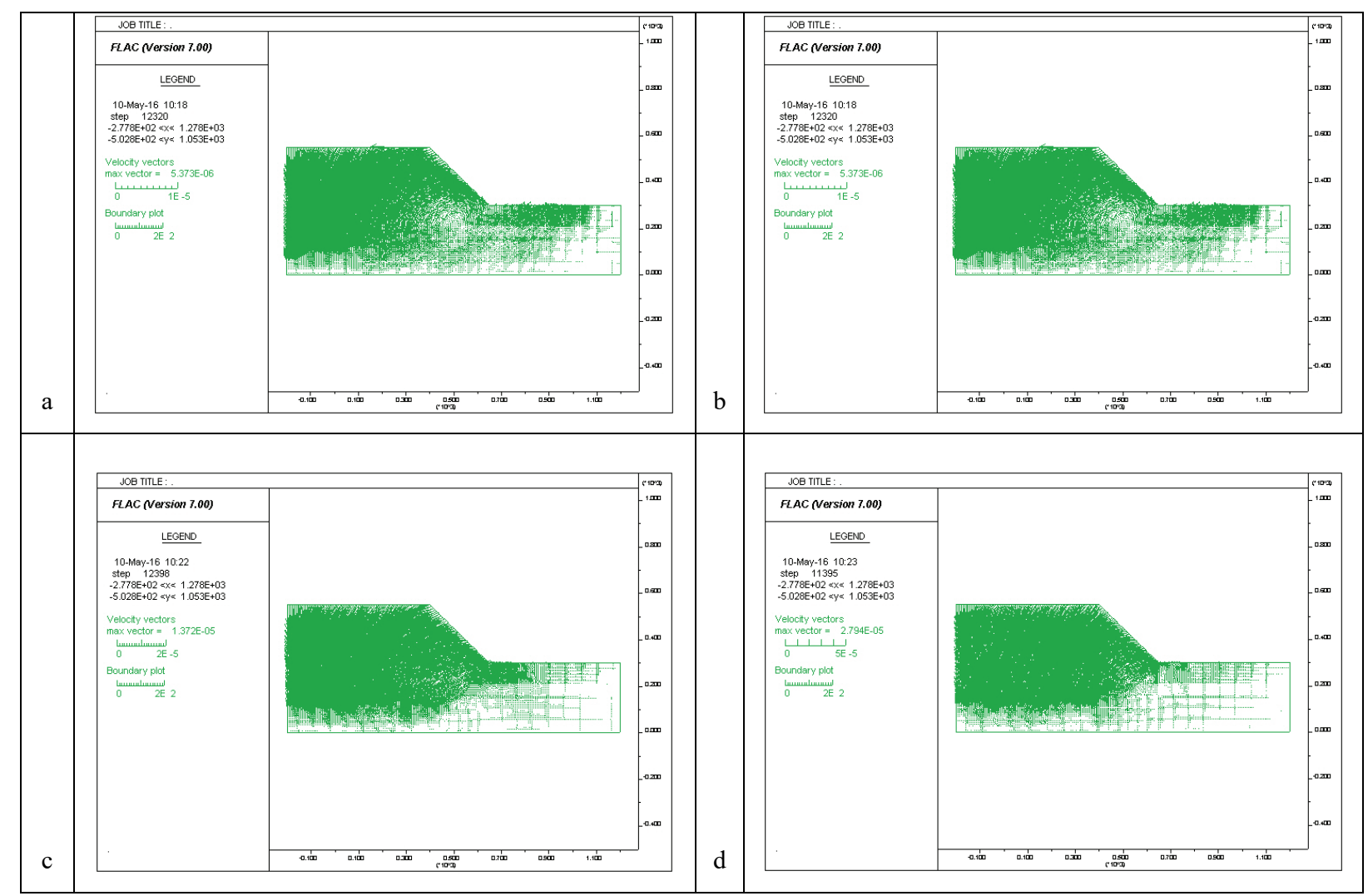




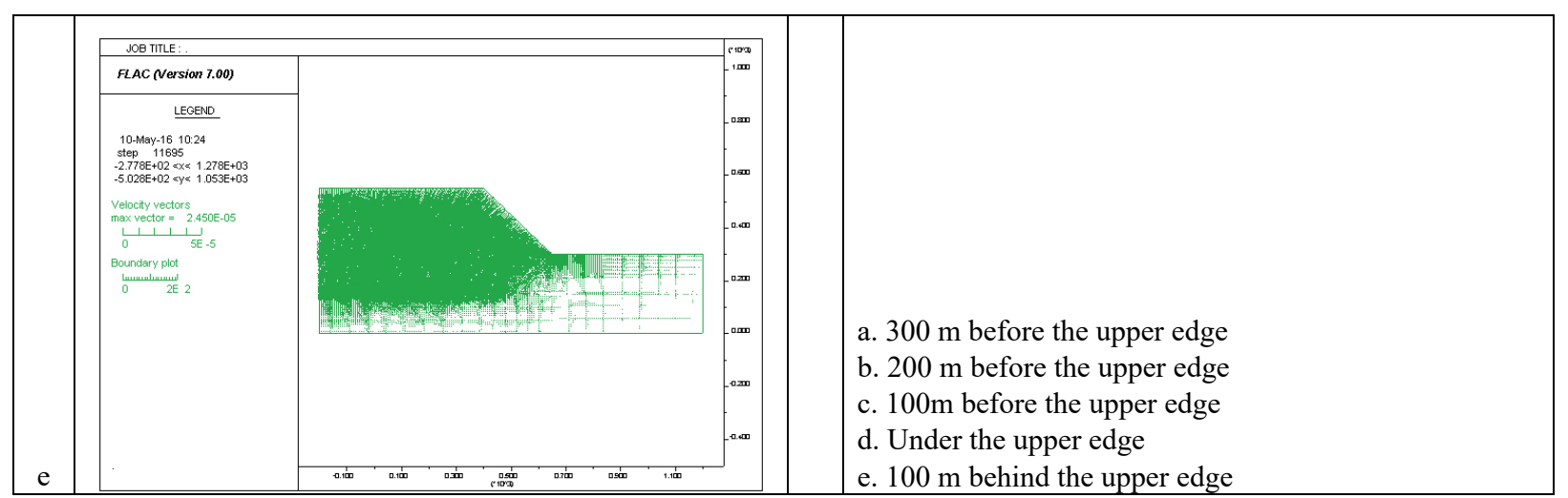

Fig. 16. Velocity vectors at particular stages of the longwall operation proceeding from the right side towards the lower edge of slope (measured point is the face of the longwall panel)

Case III: Longwall operation proceeds from the right side towards the lower edge of the open pit slope

In this case, vertical displacements begin to increase significantly, when the longwall face is located approx. $100 \mathrm{~m}$ before the lower edge of the slope (Fig. 17). Further progress of the longwall results in the situation that after reaching $100 \mathrm{~m}$ behind the lower edge of the slope, the vertical displacement rises to $1.85 \mathrm{~m}$ at the pit floor and $1.7 \mathrm{~m}$ at the lower edge of the slope. The horizontal displacements are directed towards the pit floor, which can generate an activation of landslide. The value of the horizontal displacements in the lower part of the slope is approximately $1.0 \mathrm{~m}$ (Fig 18).

The plasticity indicator shows where the failures have formed (Fig. 19b). It signals the possibility of slope landslide after the longwall face, reaching $100 \mathrm{~m}$ behind

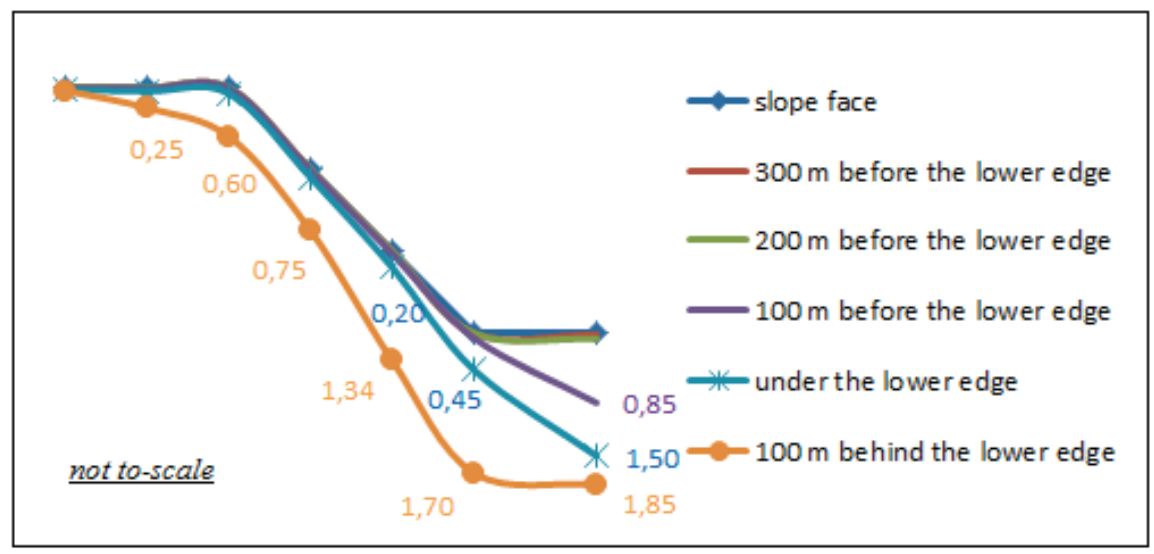

Fig. 17. Vertical displacement of slope face when the longwall operation proceeds from the right side toward the lower edge of slope (measured point is the face of the longwall panel)

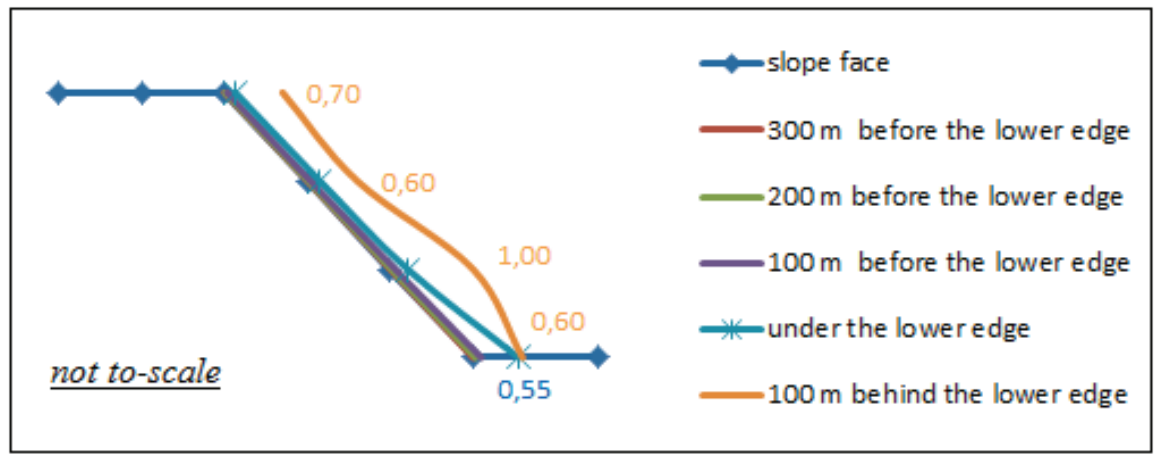

Fig. 18. Horizontal displacement of slope face when the longwall operation proceeds from the right side toward the lower edge of slope (measured point is the face of the longwall panel) 


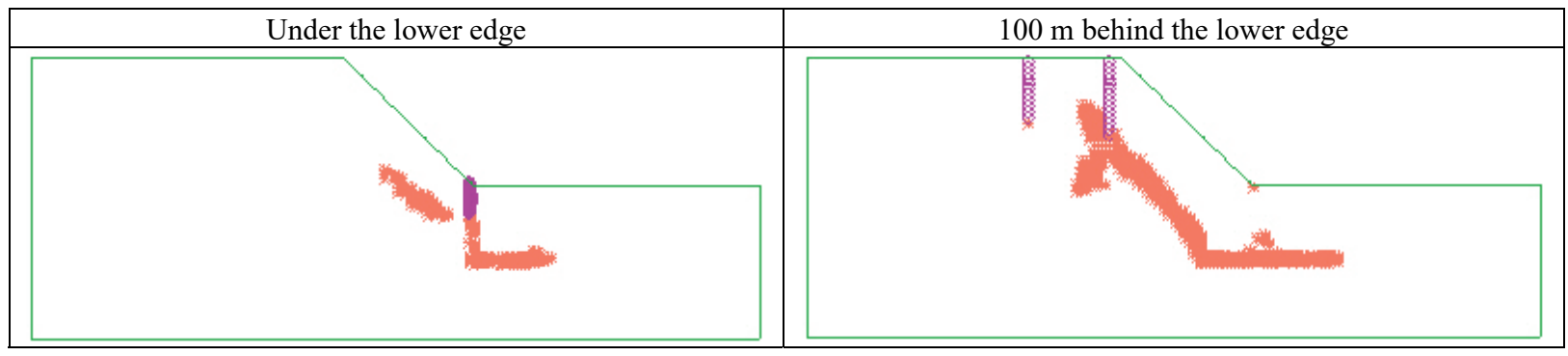

Fig. 19. Plastic indicator at particular stages of the longwall operation proceeding from the right side towards the lower edge of slope (measured point is the face of the longwall panel)

(Note: violet color shows tension failure while red color shows shear failure)

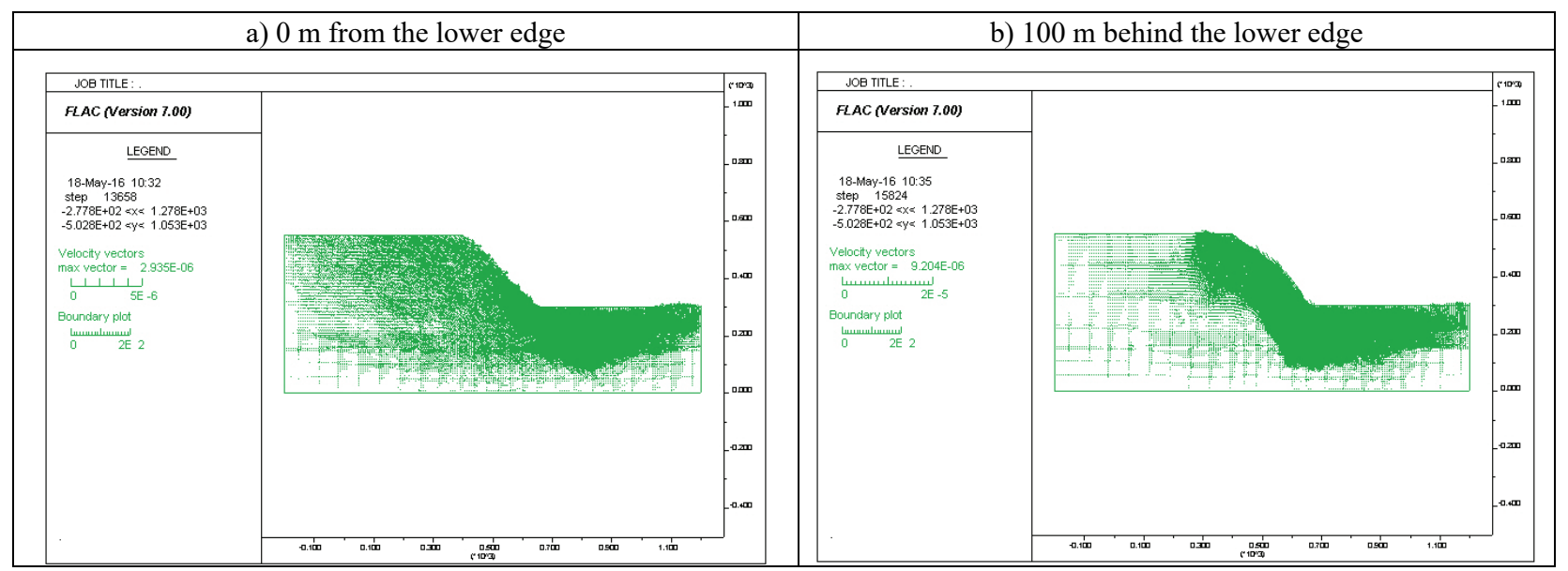

Fig. 20. Velocity vectors at particular stages of the longwall operation proceeding from the right side toward the lower edge of slope (measured point is the face of the longwall panel)

the lower edge. Further process of longwall operation could cause the failures by tension and shear in the upper part of the slope and, hence, the loss of stability.

Maximum velocity vectors are 3 times greater when the exploitation proceeds from the lower edge (Fig. 20a) to $100 \mathrm{~m}$ behind the lower edge in the direction of the slope (Fig. 20b). This indicates the possibility of failures in the face slope. The direction of the velocity vectors shown is unfavorable from the point of view of slope stability.

\section{CONCLUSIONS}

Based on the analysis performed by using numerical program FLAC 2D for underground mining operating in the area of open pit slope, for the geological and mining conditions of Quang Ninh coal basin in Vietnam, the following conclusions may be drawn:

- The zone located at a distance from 200 meters before the upper edge and $200 \mathrm{~m}$ before the lower edge of the slope is strongly affected by underground mining operation, hence it is not recommended to operate underground workings in this zone;

- For the operation of longwall panel with the caving method, performed from the left side toward the upper edge of the slope, the operation can be carried out up to 100 meters before the upper edge, whereas in the case of the direction of the longwall panel performed from the right side toward the lower edge, the operation should be completed around $100 \mathrm{~m}$ before the bottom edge of the slope;

- In realistic conditions there are many other factors affecting slope stability, e.g., underground water, tectonic disturbance, presence of weak layers of rock, heterogeneity of rock mass and change of rock mass properties due to underground operation. It is necessary to take all those factors into account for further studies of interaction between $\mathrm{UG}$ and OP.

- In general, a 2D model indicates the impact of underground mining on slope stability. However, the rock mass structure and geometry are spatial and complex, therefore it is also necessary to use a threedimensional numerical modeling for certain cases. 


\section{REFERENCES}

[1] Ahmed H.M., Eberhardt E., Dunbar W.S., Interaction between block caving and rock slope deformation kinematics as a function of cave position and orientation of discontinuities, Institute of Materials, Minerals and Mining and The Aus. IMM, 2014.

[2] Bai M., Kendorski F., Van Roosendaal D., Chinese and North American high-extraction underground coal mining strata behavior and water protection experience and guidelines, Proceedings of the 14th International Conference on Ground Control in Mining, Morgantown 1995.

[3] Brummer R., Li H., Moss A., The Transition from Open Pit to Underground Mining: an Unusual Slope Failure Mechanism at Palabora, Proceedings Int. Symposium on Stability of Rock Slopes, Cape Town 2006.

[4] BUDRYK W., Wyznaczanie wielkości poziomych odkształceń terenu, Archiwum Górnictwa i Hutnictwa, 1953, t. 1, z. 1, Kraków.

[5] Campbell A.D., Mu E., Lilley C.R., Cave propagation and open pit interaction at the Ernest Henry mine, Seventh International Conference and Exhibition on Mass Mining, Sydney 2016.

[6] DuplanciC P., BRady B.H., Characterisation of caving mechanisms by analysis of seismicity and rock stress, Proc. 9th Congr. Int. Soc. Rock Mech., Paris 1999.

[7] FLORKOWSKA L., Modelowanie numeryczne wplywu górniczych deformacji podtoża na grupę budynków w zwartej zabudowie miejskiej, Górnictwo i Geoinżynieria, 2009, Rok 33, Zeszyt 1.

[8] Gonot J., Teoria kierunku pękania, Liege 1858.

[9] Itasca, FLAC 2D version 7.0. (2011). Minneapolis, MN, Itasca Consulting Group Ltd. Available: http://www.itascacg.com

[10] KWAŚnIEWSKi M., WANG J., Analiza numeryczna deformacji górotworu wywołanych eksploatacja górnicza, Materiały Szkoły Eksploatacji Podziemnej, Kraków 1996.

[11] KNOTHE S., Wplyw podziemnej eksploatacji na powierzchnie z punktu widzenia zabezpieczenia położonych na niej obiektów, Praca doktorska AGH, Kraków 1951.

[12] Knothe S., Prognozowanie wpływów eksploatacji górniczej, Wyd. Śląsk, Katowice 1984.

[13] KOCHMAŃSKI T., Obliczanie ruchów punktu górotworu pod wplywem eksploatacji górniczej, Państwowe Wyd. Nauk., Warszawa 1956.

[14] LISOwSKI A., Kierunek eksploatacji ścian zawałowych, Prace GiG, Katowice 1959.

[15] Mazurkiewicz M., Piotrowski Z., Tajduś A., Lokowanie odpadów w kopalniach podziemnych, część II, Kraków 1997.

[16] Moss A., Diachenko S., Townsend P., Interaction between the Block Caving and the pit slope at Palabora mine, The South African Institute of Mining and Metallurgy, International Symposium, Stability of Rock Slopes in Open Pit Mining and Civil Engineering Situations, 2006.
[17] NAWROT W., Właściwości mechaniczne utworów skalnych o strukturze blokowo-warstwowej, Praca Doktorska, Kraków 1972.

[18] Ngidi S., Boshoff P., Cave management and secondary breaking practices at Palabora mining company, The Southern African Institute of Mining and Metallurgy, 6th Southern African Base Metals Conference, 2011.

[19] Peng S.S., Chiang H.S., Longwall Mining, John Wiley \& Sons, Inc., New York 1984.

[20] Peng S.S., Coal mine Ground Control, John Wiley \& Sons Inc, New York 1986.

[21] Piwowarski W., Dżegniuk B., Niedojadło Z., Wspótczesne teorie ruchów górotworu i ich zastosowania, Wydawnictwo AGH, Kraków 1995.

[22] ROPSKI S., Stan petnego i wysokiego zawatu oraz stref osiadania stropu za ściana na podstawie pomiarów w kopalni ,Wesoła" w pokładzie 329, Praca doktorska, Kraków 1964.

[23] Salustowicz A., Zarys mechaniki górotworu, Katowice 1968.

[24] Severin J., Eberhardt E., NGidi S., Stewart A., Importance of understanding 3-D kinematic controls in the review of displacement monitoring of deep open pits above underground mass mining operations, Proceedings of the 3rd CANUS Rock Mechanics Symposium, Toronto 2009.

[25] STAROŃ T., Eksploatacja pokładów wegla z zawałem stropu w sąsiedztwie pól pożarowych, Wyd. Śląsk, Katowice 1979.

[26] TAJduś K., Określanie wartości parametrów odksztatceniowych górotworu uwarstwionego $w$ rejonie wplywów eksploatacji górniczej, Doctoral Dissertation, Kraków 2008.

[27] VisSER W.F., Optimization of the OP/UG Transition. Department of Applied Earth Sciences, Delft University of Technology, The Netherlands 2006.

[28] VyAZMENSKY A., Numerical modeling of Surface subsidence associated with Block Caving Mining using a Finite Element/Discrete Element Approach, PhD thesis, Simon Fraser University, 2008.

[29] Wesolowski M., Bialek J., Kolodziejczyk P., Plewa F., Modelowanie wplywów eksploatacji górniczej przy wykorzystaniu modeli numerycznych, Gliwice 2010.

[30] WesOŁOWSKI M., Zastosowanie liniowego ośrodka transwersalnie izotropowego do modelowania deformacji terenu górniczego, Gliwice 2013.

[31] Woo K.S., Eberhardt E., Ghuman P., Stead D., Integration of $3 D$ numerical modelling and InSAR deformation monitoring to characterize Block Caving induced surface subsidence, Australian Centre for Geomechanics, Perth 2010.

[32] YU X., Prognozowanie deformacji powierzchni na terenach górzystych pod wplywem eksploatacji górniczej, Praca doktorska przedłożona Radzie Wydziału Górniczego Akademii Górniczo-Hutniczej im. Stanisława Staszica w Krakowie, 1998.

[33] ZnAŃski J., Przemieszczenie górotworu w otoczeniu przodka ścianowego, Przegląd Górniczy, 1958, Nr. 11. 